Fakultas Hukum, Universitas Lampung, Bandar Lampung, Lampung, Indonesia. http://jurnal.fh.unila.ac.id/index.php/corruptio

Volume 01 Issue 1, January - June 2020. PP: 15-26

P-ISSN: 2723-2573

E-ISSN: 2745-9276

\title{
Pertanggungjawaban Pelaku Tindak Pidana Narkotika dan Tindak Pidana Pencucian Uang
}

\author{
Accountability of Narcotics and Money Laundering Offenders
}

\author{
Ivan Kurniawan \\ ivankurniawan1610@gmail.com \\ Fakultas Hukum Universitas Lampung
}

Submitted: Feb 28, 2020; Reviewed: Mar 16, 2020; Accepted: Apr 20, 2020

\begin{abstract}
Info Artikel
Kata Kunci: Pertanggungjawaban Pidana; Narkotika; Pencucian Uang.

Keywords: Criminal Liability; Narcotics; Money laundering.
\end{abstract}

DOI:

https://doi.org/10.25041/corruptio.v1i1.2070
Tindak pidana narkotika merupakan salah satu kejahatan luar biasa sehingga diatur secara khusus dalam undangundang tersendiri yaitu Undang-Undang Nomor 35 Tahun 2009 tentang Nark.otika. Para pelaku maupun pihakpihak lain yang terlibat dalam tindak pidana narkotika tentunya memahami kosekuensi berat terhadap apa yang mereka lakukan. Berkenaan dengan permasalahan di atas, terdapat satu putusan yang menarik untuk dikaji dan dianalisis, yang telah diputuskan oleh majelis hakim adalah putusan nomor: 124/Pid.Sus/2016/PN.TJK yang mana pelaku melakukan dua delik sekaligus sehingga penjatuhan hukuman pun apakah sudah berkeadilan. Studi ini akan fokus kepada permasalahan hukum yakni mengetahui pertanggungjawaban terhadap pelaku tindak pidana narkotika dan tindak pidana pencucian uang. menganalisa 
putusan pengadilan Nomor:

124/Pid.Sus/2016/PN.TJK apakah sudah memenuhi rasa keadilan yang berkemanfaatan. Penelitian ini menggunakan pendekatan Yuridis Normatif dengan menganalisis suatu putusan pengadilan. Adapun hasil penelitian yang didapatkan bahwa: Menurut analisis peneliti dilihat dari pertanggungjawaban pidananya sudah memenuhi unsur kesalahan, kemampuan bertanggungjawab, sikap batin jahat, dan tidak ada alasan pemaaf. dan Putusan Pengadilan Nomor: $\quad$ 124/Pid.Sus/2016/PN.TJK sudah memenuhi rasa keadilan yang berkemanfaatan. Berdasarkan penelitian menunjukan bahwa putusan yang diberikan sudah termasuk adil karena perbuatan terdakwa tersebut sudah merusak generasi bangsa dan mengingat perbuatan terdakwa tersebut melakukan dua delik sekaligus yakni melanggar Pasal 131 Undang-Undang Nomor 35 Tahun 2009 tentang Narkotika dan Pasal 5 ayat (1) huruf c UndangUndang Nomor 8 Tahun 2010 tentang Pencegahan serta Pemberantasan Tindak Pidana Pencucian Uang. Adapun saran yang dapat disampaikan dalam penelitian ini Sebaiknya polisi dalam upaya mencegah terjadinya peredaran narkotika dan pencucian uang agar berkoordinasi dengan baik kepada pusat penelusuran analisis transaksi keuangan dan juga badan pertanahan nasional agar aset-aset para pengedar atau penjual narkoba bisa terlacak dengan baik.

\section{Abstract}

The narcotics crime is one of the extraordinary crimes so that it is specifically regulated in act of Law Number 35 Year 2009 concerning Narcotics. The perpetrators and other parties involved in narcotics crime certainly understand the severe 
consequences of what they do. In connection with the above problem, there is one interesting decision to be reviewed and analyzed, which has been decided by the panel of judges is the decision number: 124 / Pid.Sus / 2016 / PN.TJK in which the perpetrator commits two offenses at once so that the sentence could be sentenced whether it has been be fair. This study will focus on legal issues, namely knowing the responsibility of the perpetrators of narcotics and money laundering crimes. analyze the court's decision Number: 124 / Pid.Sus / 2016 / PN.TJK whether it has fulfilled a sense of justice that is beneficial. This study uses a Normative Juridical approach by analyzing a court decision. As for the results of the study found that: According to the analysis of researchers seen from the criminal responsibility has fulfilled the elements of error, the ability to be responsible, evil inner attitude, and there is no reason to forgive. Court Decision Number: 124 / Pid.Sus / 2016 / PN.TJK has fulfilled a useful sense of justice. Based on research shows that the verdict given is considered fair because the defendant's actions have damaged the nation's generation and remembering that the defendant's actions committed two offenses namely violating Article 131 of Law Number 35 Year 2009 concerning Narcotics and Article 5 paragraph (1) letter $c$ of the Act Law Number 8 of 2010 concerning Prevention and Eradication of Money Laundering Crimes. As for the suggestions that can be submitted in this study, it is better for the police in an effort to prevent the circulation of narcotics and money laundering so that they coordinate well with the financial transaction analysis tracking center and also the national land agency so that the assets of drug dealers or traffickers can be properly tracked. 


\section{A. Pendahuluan}

Kejahatan narkoba merupakan kejahatan international (International Crime), kejahatan yang terkoorganisir (Organize Crime), mempunyai jaringan yang luas, mempunyai dukungan dana yang besar dan sudah menggunakan teknologi yang canggih. Narkoba mempunyai dampak negatif yang sangat luas, diantaranya secara fisik, ekonomi, psikis dan lain-lain. ${ }^{1}$ Penyalahgunaan narkoba dapat menimbulkan dampak kerugian terhadap kondisi kesehatan jasmani, begitu juga kondisi psikis pengguna narkotika. ${ }^{2}$ Kemudian menurut Undang-Undang No. 22 tahun 1997 tentang Narkotika, menyatakan bahwa Narkotika adalah singkatan dari narkotika, psikotropika dan bahan adiktif lainnya. ${ }^{3}$ Secara umum narkoba adalah obat legal yang digunakan dalam dunia kedokteran, namun dengan perkembangan zaman sekarang ini yang makin canggih maka, Narkoba banyak disalahgunakan. Bahkan kalangan muda banyak sekali yang menggunakan narkoba. Banyak dari mereka yang menggunakan Narkoba dengan alasan untuk kesenangan batin, namun sayangnya tidak banyak yang mengetahuai bahaya narkoba. ${ }^{4}$

Penyalahgunaan obat-obatan yang terlarang ini merupakan suatu ancaman dan permasalahan yang komplek yang dapat menghancurkan generasi bangsa. Sampai saat ini masih banyak masyarkat yang belum sadar dan paham tentang bahaya penyalahgunaan NAPZA (Narkotika, Psikotropika, dan zat adiktif lainnya). Penyalahgunaan NAPZA bisa mengakibatkan kecanduan dan mengakibatkan ganguan secara klinis atau fungsi sosial. ${ }^{5}$ Bahaya yang ditimbulkan dari penyalahgunaan narkoba dapat dilihat dari bebagai aspek, diantaranya aspek kesehatan, aspek ekonomi, aspek social, aspek kemanan, dan aspek hukum. ${ }^{6}$

Problematika narkoba di kalangan masyarakat menurut Erwin Mappaseng dibagi menjadi tiga bagian yang sering terkait, yakni adanya distibusi obat-obatan terlarang secara illegal (illicit drug production), adanya transaksi dagang secara illegal antar negara (illicit trafficking) dan adanya penyalahgunaan narkoba di kalangan remaja (drug abuse). Remaja dalam hal melakukan penyalahgunaan NAPZA tentunya dipengaruhi faktor-faktor yakni, dari faktor internal keluarga seperti hubungan antara anggota keluarga tidak harmonis, keluarga yang tidak utuh, kurang komunikasi antar anggota keluarga, keluarga terlalu mengekang kehidupan pribadi, keluarga yang kurang mengamalkan hidup beragama dan keluarga yang orang tuanya telah menggunakan NAPZA. Faktor lain yang merupakan faktor eksternal berasal dari pengaruh buruk dari lingkungan pergaulan, khususnya pengaruh dari luar seperti kelompok teman sebaya dan kurangnya perhatian dari pemerintah. ${ }^{7}$ Faktor-faktor tersebut yang menyebabkan negara-negara sangat gencar dalam memerangi bahayanya peredaran narkotika. ${ }^{8}$

\footnotetext{
${ }^{1}$ Fransiska Novita Eleanora, "Bahaya Penyalahgunaan Narkoba Serta Usaha Pencegahan Dan Penanggulangannya (Suatu Tinjauan Teoritis)." Jurnal Hukum: Fakultas Hukum Uinssula. Vol XXV.No. 1. (2011). hlm.440.

${ }^{2}$ Meta Adeana Wulansari, "Pengembangan Buku Panduan Pencegahan Bahaya Narkoba Bagi Siswa Sekolah Menengah Pertama." Jurnal Bk UNESA. Vol. 8. No. 1 (2018). Hlm. 2.

${ }^{3}$ Dewi Iriani, "Kejahtan Narkoba: Penaggulangan, Pencegahan dan Penerpan Hukuman Mati." Jurnal Islamica. Vol. 12. No. 2. (2015). hlm.307.

${ }^{4}$ Mellisa Fitri \& Sumringah Migunani. "Sosialisasi Dan Penyuluhan Narkoba.” Jurnal Inovasi Dan Kewirausahaan. Vol. 3 No. 2. (2014). Hlm.73.

5 Qomariyatus Sholihah, "Efektivitas Program P4gn Terhadap Pencegahan Penyalahgunaan Napza." Jurnal Kesehatan Masyarkat. Vol.9. No. 10. No. 2. (2015). Hlm.155.

${ }^{6}$ Primanita Aisiy Nur Habibah, "Meningkatkan Pemahaman Siswa Tentang Bahaya Penyalahgunaan Narkoba Melalui Layanan Informasi." Indonesia Journal of Guidance and Counseling: Theory and Aplication.

7 Catur Mei Wulandari, Diyan Ajeng Retnowati, Kukuh Judi Handojo \& Rosida. "Faktor-Faktor Yang Mempengaruhi Penyalahgunaan Napza Pada Masyarakat Di Kabupaten Jember." Jurnal Farmasi Komunitas. Vol. 2. No. 1. (2015). Hlm.3.

${ }^{8}$ Erwin Mappaseng, Pemberantasan dan Pencegahan Narkoba yang dilakukan oleh polri dalam Aspek Hukum dan Pelaksanaannya, Buana Ilmu, Surakarta, 2002, hlm.2.
} 
Kejahatan narkotika tersebut mengalami peningkatan dari tahun-ketahun tidak habishabisnya, para bandar narkoba atau pemasok dari dalam negeri maupun di luar negeri ditangkap dan bahkan ada yang dihukum mati. Gencarnya perdagangan gelap narkotika ini dipelopori oleh negara-negara penyuplai narkoba agar dikirim ke beberapa negara target penjualan narkoba salah satunya yang menjadi incaran target perdagangan besar narkotika ini adalah Indonesia. ${ }^{9}$ Masalah penyalahgunaan NAPZA atau istilah yang populer dikenal masyarakat sebagai narkotika merupakan masalah yang sangat kompleks, yang memerlukan upaya penanggulangan secara komprehensif dengan melibatkan kerja sama multidispliner, multisektor, dan peran serta masyarakat secara aktif yang dilaksanakan secara berkesinambungan, konsekuen dan konsisten. ${ }^{10}$

Para kurir-kurir narkotika dan juga produsen atau bandar narkoba biasanya memiliki harta yang berlimpah karena hasil kekayaannya disamarkan menggunakan tindak pidana pencucian uang yang merupakan proses menyamarkan hasil kejahatan dengan ditukar menjadi aset-aset yang berharga. ${ }^{11}$ Sebagaimana pendapat Sjahdeini yang mengatakan bahwa tindak pidana pencucian uang adalah metode atau cara yang dilakukan oleh orang maupun korporasi terhadap suatu hasil kejahatan yang diolah sehingga dapat disembunyikan asal usulnya dari hasil kejahatan yang dilakukan agar tujuannya mengelabui para penegak hukum sehingga sulit dilacak. $^{12}$ Perbuatan pelaku yang melakukan peredaran gelap narkotika dengan cara menyamarkan atau mengelabui harta atau aset hasil kejahatan melalui sistem transasksi keuangan dengan tujuan menjauhkan pelaku dari kejahatan yang diperbuatnya proceeds of crime dengan harapan hasil kejahatan yang dihasilkan tersebut seolah-olah sah ketika dimasukan ke dalam rekening bank sehingga ketika dilacak oleh para penegak hukum tidak dapat diketahui dan tidak dapat diidentifikasi bahwa harta kekayaan tersebut ternyata dari hasil tindak pidana narkotika. ${ }^{13} \mathrm{Hal}$ ini sesuai dengan pengertian pencucian uang, yakni suatu upaya perbuatan untuk menyembunyikan atau menyamarkan asal usul uang/dana atau harta kekayaan hasil tindak pidana melalui berbagai transaksi keuangan agar uang atau harta kekayaan tersebut tampak seolah-olah berasal dari kegiatan yang sah/legal. ${ }^{14}$ Tindak pidana pencucian uang biasa disebut dengan money laundry, di Indonesia sendiri masalah ini masih belum terselesaikan. Kejahatan pencucian uang juga menjadi masalah kejahatan transnasional yang tersistematis karena bekerjanya hukum nasional dalam konteks kerjasama internasional sebagaimana yang telah dihimbau oleh UNCAC Tahun 2003 yang berupa kewajiban negaranegara peserta untuk mengambil tindakan-tindakan pencegahan melalui hukum nasionalnya serta mewajibkan setiap negara untuk mengadopsi sesuai dengan prinsip-prinsip hukum nasionalnya, tindakan-tindakan legislatif dan tindakan-tindakan lain yang diperlukan, untuk menangani kegiatan-kegiatan yang digolongkan kedalam bentuk tindak pidana pencucian uang. ${ }^{15}$

Berkenaan dengan permasalahan di atas, terdapat satu putusan yang menarik untuk dikaji dan dipahami, adalah putusan nomor: 124/Pid.Sus/2016/PN.TJK dengan terdakwa bernama Tarmizi bin Abdullah, terbukti secara sah dan meyakinkan melakukan tindak pidana turut

\footnotetext{
${ }^{9}$ Dharana Lastarya, Narkoba, Perlukah Mengenalnya, Pakarkarya, Jakarta, 2006, hlm.15.

${ }^{10}$ Adik Septiano Putra , Ni Putu Raiyuliartini , Dewa Gede Sudika Mangku. "Sistem Pembinaan Terhadap Narapidana Narkotika Di Lembaga Pemasyarakatan Kelas Ii B Singaraja." E-Journal Komunitas Yustisia Universitas Pendidikan Ganesha Program Studi Ilmu Hukum. Vol. 2. No. 1. (2019).

${ }^{11}$ Adrian Sutedi, Tindak Pidana Pencucian Uang, Citra Aditya Bakti, Bandung, 2008, hlm. 182

${ }^{12}$ Sutan Remy Sjahdeini. Pertanggungjawaban Pidana Korporasi, Rineka Cipta, Jakarta, 2007, hlm.5.

${ }^{13}$ Bismar Nasution, Hukum Kegiatan Ekonomi I, Books Terrace \& Library, Bandung,2007, hlm. 219

${ }^{14}$ M. Fadra Heryndra, "Kajian Yuridis Kriteria Tentang "Personil Pengendali Korporasi” Terkait Pertanggungjawaban Pidana Korporasi Berdasarkan Pasal 6 ayat (1) Undang-undang Republik Indonesia Nomor 8 Tahun 2010 Tentang Pencegahan dan Pemberantasan Tindak Pidana Pencucian Uang.” Jurnal Hukum Brawijaya. 2020.

15 Tomi Mulyana, "Kedudukan Jaksa Kpk Dalam Penuntututan Tindak Pidana Pencucian Uang Hasil Dari Tindak Pidana Korupsi." Jurnal Humaniora Scientica. Vol. Ii No. 1. (2015).
} 
serta menerima sumbangan, penitipan atau menggunakan harta kekayaan hasil tindak pidana narkotika, sebagaimana diatur dalam pasal 131 Undang-Undang Nomor 35 Tahun 2009 tentang Narkotika, yang menyatakan bahwa pelaku yang melakukan kejahtan narokotika Dipidana dengan pidana penjara paling lama 1 (satu) tahun atau pidana denda paling banyak Rp50.000.000,00 (lima puluh juta rupiah). ${ }^{16}$

Majelis hakim menjatuhkan pidana terhadap terdakwa dengan pidana penjara selama 3(tiga) tahun dan 6 (enam) bulan dan denda sejumlah Rp. 200.000.000,00 (dua ratus juta rupiah) dengan ketentuan apabila denda tidak dibayar maka diganti dengan penjara selama 3 (tiga) bulan. Pidana yang dijatuhkan hakim ini melebihi ketentuan maksimal sebagaimana diatur pasal 131 Undang-Undang No 35 Tahun 2009, mengingat adanya gabungan delik dalam tindak pidana.

Berdasarkan latar belakang tersebut di atas, maka persoalan yang akan dibahas dalam penelitian ini adalah bagaimanakah pertanggungjawaban terhadap pelaku tindak pidana narkotika dan tindak pidana pencucian uang dalam putusan Nomor: 124/Pid.Sus/2016/PN.JK? Apakah putusan pengadilan Nomor: 124/Pid.Sus/2016/PN.TJK sudah memenuhi rasa keadilan yang berkemanfaatan?

\section{B. Pembahasan}

1. Pertanggungjawaban Terhadap Pelaku Tindak Pidana Narkotika Dan Tindak Pidana Pencucian Uang Dalam Putusan Nomor: 124/Pid.Sus/2016/PN.JK.

Pertanggungjawaban pidana harus didahului dengan pembahasan tentang konsep perbuatan pidana. Sebab, tidak adil jika seorang harus bertanggung jawab atas suatu perbuatan, sedang ia sendiri tidak melakukan suatu tindak pidana. ${ }^{17}$ Pertanggungjawaban pidanaberkiatan dengan persoalan keadilan. Pertanggungjawaban pidana lahir dengan diteruskannya celaan yang objektif terhadap perbuatan yang dinyatakan sebagai tindak pidana berdasarkan hukum pidana yang berlaku, yang secara subjektif kepada pembuat yang memenuhi persyaratan untuk dapat dikenai pidana karena perbuatan tersebut. ${ }^{18}$ Pada intinya dalam hukum pidana harus ada kesalahan yang menyertai suatu perbuatan, yang mana perbuatan tersebut bertentangan dengan peraturan perundang-undang. ${ }^{19}$

Pertanggungjawaban pidana menurut Menurut Aiptu Hendriyono selaku penyidik pada Satuan Unit Narkoba Polresta Bandar Lampung yang harus diperhatikan adalah dengan melihat Means Reanya yang artinya bahwa ketika pebuatan pelaku tersebut memiliki arti kesalahan maka harus dilihat dulu dari sikap batinnya apakah perbuatan pelaku tersebut dalam melakukan tindak pidana murni karena motif atau rencana dan tujuan atau justru dikarenakan jiwanya tidak dapat dipertanggungjawabkan.

Menurut Aiptu Hendriyono selaku penyidik pada Satuan Unit Narkoba Polresta Bandar Lampung bahwa dalam hal pemidanaan, maka pertanggung-jawaban dari tiap pelaku dibatasi pada tiap-tiap perbuatan yang dilakukan dan tidak dapat digantungkan pertanggungjawabannya itu kepada apa yang diperbuat oleh orang lain, begitu pula pemidanaanya

\footnotetext{
16 Oci Senjaya. "Perbandingan Undang-Undang Nomor 35 Tahun 2009 Tentang Narkotika Dengan Ruu Kuhp Indonesia Berkaitan Dengan Sistem Pemidanaan Terhadap Pelaku Tindak Pidana Penyalahguna Narkotika." Jurnal Hukum Positum. Vol. 3, No. 1 (2018).hlm. 95.

${ }^{17}$ Oksimana Darmawan, "Pertanggungjawaban Pidana Korporasi Dalam Illegal Fishing Di Indonesia.” Jurnal Yudisial. Vol. 11 No. 2. (2018). Hlm. 183.

${ }^{18}$ Tommy J. Bassang, "Pertanggungjawaban Pelaku Tindak Pidana Deelneming." Jurnal Lex Crimen. Vol. Iv. No. 5. (2015) Hlm.124.

${ }^{19}$ Henry Donald Lbn. Toruan, "Pertanggungjawaban Pidana Korupsi Korporasi." Jurnal Rechtsvinding. Vol. 3. No. 3. (2014).
} 
melainkan menurut sikap batinnya masing-masing berhubungan dengan apa yang diperbuatnya. $^{20}$

Menurut Aiptu Hendriyono selaku penyidik pada Satuan Unit Narkoba Polresta Bandar Lampung. Apa yang dimaksud dengan pelaku harus mampu bertanggung-jawab pelaku harus secara sadar mengetahui dan menghendaki baik dari segi kematangan/kedewasaan dan subjek hukum yang melakukan pelaku tindak pidana narkotika dan tindak pidana pencucian uang tersebut haruslah orang yang normal dalam artian dia tidak mengalami gangguan jiwa/ keadaan cacat dari lahir serta terdakwa mengetahui maksud dari perbuatan yang dilakukannya. $^{21}$

Menurut Erna Dewi selaku Akademisi Fakultas Hukum dari Universitas Lampung menyatakan bahwa harus dikaji terlebi dahulu dalam kaitannya pemberian sanksi pidana kepada seseorang yang melakukan tindak pidana, minimal dua yang harus di perhatikan dalam hal ini yakni perbuatan tersebut sudah memenuhi unsur pidananya di dalam ketentuan undang-undang (actus reus) dan juga perbuatan pelaku tersebut harus bersifat melawan hukum (onrechtmatig). ${ }^{22}$

Menurut peneliti kemampuan bertanggung-jawab seseorang pertama harus dilihat dari keadaan batin dan kedua kedewasaan seseorang yakni sebagai berikut:

\section{a. Unsur Kesalahan}

Kesalahan adalah keadaan psychis orang yang melakukan perbuatan dan hubungannya dengan perbuatan yang dilakukan, yang sedemikian rupa sehingga orang itu dapat dicela karena perbuatan tadi. Menurut analisis peneliti bahwa unsur kesalahan ini terlihat bahwa terdakwa Tarmizi bin Abdullah mengetahui kalau topik mempunyai pekerjaan menjual narkotika tetapi tidak dilaporkan oleh Terdakwa Tarmizi bin Abdullah pihak kepolisian RI ataupun kepada Badan Narkotika Nasional dan juga terdakwa topik secara sengaja menyewakan rumah tinggalnya kepada Topik yang jelas-jelas dalam hal ini dipergunakan untuk menjual narkoba kemudian hasil dari penjualan narkoba tersebut dibayarkan Topik untuk menyewa rumah Terdakwa, yang mana uang sewa rumah dari penjualan hasil narkoba tersebut dipergunakan terdakwa sejumlah Rp 10.000.000.00 (sepuluh juta rupiah) untuk keperluan biaya terdakwa di dalam Lembaga Pemasyarakatan. Asas pertanggungjawaban strict liability dalam hukum pidana Indonesia hanya dikenal sebagai doktrin namun dalam prakteknya asas strict liability sering digunakan dalam perkara pelanggaran narkotika. Strict liability dinyatakan sebagai pertanggungjawaban tanpa kesalahan (liability without fault). ${ }^{23}$

\section{b. Unsur Kemampuan Bertanggungjawab}

Bahwa menurut analisis peneliti dilihat dari pertanggungjawaban pidananya terdakwa Tarmizi Bin Abdullah terdakwa tidak cacat jiwa atau terganggu jiwanya karena terdakwa dihadapkan dalam persidangan dalam keadaan normal dan dapat menjawab semua pertanyaan hakim, dengan demikian unsur pertanggungjawaban pidana pada diri pelaku sudah terpenuhi dan dapat dipertanggungjawabkan secara hukum.

\footnotetext{
${ }^{20}$ Berdasarkan Wawancara Dengan Aiptu Hendriyono selaku penyidik pada Satuan Unit Narkoba Polresta Bandar Lampung, Pada Tanggal 15 September 2019

${ }^{21}$ Berdasarkan Wawancara Dengan Aiptu Hendriyono selaku penyidik pada Satuan Unit Narkoba Polresta Bandar Lampung, Pada Tanggal 15 September 2019

${ }^{22}$ Berdasarkan Wawancara Dengan Erna Dewi selaku Akademisi Fakultas Hukum dari Universitas Lampung, Pada Tanggal 20 September 2019

${ }^{23}$ Ridho Kurniawan \& Siti Nurul Intan Sari D, "Pertanggungjawaban Pidana Korporasi Berdasarkan Asas Strict Liability (Studi Pembaharuan Hukum Pidana Lingkungan Hidup).”Jurnal Yuridis. Vol.1 No.2. (2014).
} 


\section{c. Sikap Batin Jahat}

Bahwa dari fakta hukum tersebut di atas didukung oleh keterangan saksi Sutarsih alias Asih dan saksi-saksi lainnya bahwa seseorang yang bernama topik (yaitu saudara sepupu Terdakwa Tarmizi bin Abdullah) bekerja menjual narkotika dan tidak mempunyai pekerjaan tetap, walaupun terdakwa Tarmizi bin Abdullah mengetahui kalau topik mempunyai pekerjaan menjual narkotika tetapi tidak dilaporkan oleh Terdakwa Tarmizi bin Abdullah kepada pihak kepolisian RI, ataupun kepada Badan Narkotika Nasional.

\section{d. Tidak Ada Alasan Pemaaf}

Unsur tidak ada alasan pemaaf artinya dalam hal tindak pindana yang melakukan kejahatan narkotika dan pencucian uang biasanya lebih cenderung kepada diri pelaku tindak pidana apakah pelaku tindak pidana melanggar undang-undang narkotika dan apakah tidak melakukan ketentuan dalam undang-undang tentang pencucian uang dan melakukan tindak pidana dikarenakan atas dasar:

1) Tak mampu bertanggung jawab dikarenakan jiwannya cacat (Pasal 44 KUHP)

2) Belum berumur 16 (enam belas) tahun (Pasal 45 KUHP)

3) Daya paksa (overmacht) (Pasal 48 KUHP)

4) Pembelaan terpaksa (Pasal 49 KUHP)

5) Ketentuan Undang-Undang (Pasal 50 KUHP)

6) Perintah jabatan (Pasal 51 KUHP)

Apabila unsur yang di atas ada dalam diri pelaku, maka hakim memutuskan untuk tidak menghukum pelaku dikarenakan adanya alasan pemaaf. Berdasarkan pengertian alasan pemaaf sendiri menurut Moeljatno yakni alasan yang menghapuskan kesalahan terdakwa, yakni perbuatan yang dilakukan oleh terdakwa tetap bersifat melawan hukum dan tetap merupakan perbuatan pidana akan tetapi terdakwa tidak dipidana karena tidak ada kesalahan. ${ }^{24}$

Bahwa menurut analisis peneliti bahwa majelis Hakim dalam putusannya berpendapat bahwa terdakwa telah terbukti secara sah dan meyakinkan bersalah dan tidak ada alasan pemaaf yang mana perbuatan terdakwa tersebut tidak dapat ditolerir karena merusak jiwa generasi bangsa dengan melakukan tindak pidana dengan sengaja tidak melaporkan adanya tindak pidana narkotika dan turut serta menerima sumbangan, penitipan, atau menggunakan harta kekayaan yang diketahuinya hasil tindak pidana narkotika."

Sebagaimana tercantum dalam dakwaan pertama: ketiga dan kedua kedua sehingga melanggar Pasal 131 Undang-Undang Nomor 35 Tahun 2009 tentang Narkotika, Pasal 5 ayat (1) huruf c Undang-Undang Nomor 8 Tahun 2010 tentang Pencegahan serta Pemberantasan Tindak pidana Pencucian Uang Jo Pasal 55 ayat (1) ke-1 KUHP, Undang-Undang dan Peraturan Perundang-Undangan lain yang berkaitan dengan perkara ini.

\section{Putusan Pengadilan Nomor: 124/Pid.Sus/2016/PN.TJK Sudah Memenuhi Rasa Keadilan yang Berkemanfaatan}

Menurut Mansur Bustami selaku Hakim Pada Pengadilan Negeri Kelas I A Tanjung Karang sebagaimana telah diuraikan sebelumnya, dalam praktiknya, Hakim menjatuhkan putusan di Pengadilan Negeri Tanjung Karang Nomor: 124/Pid.Sus/2016/PN.TJK mempertimbangkan hal-hal yang memberatkan dan hal-hal yang meringankan terdakwa. Hal yang memberatkan antara lain, yaitu terdakwa pernah dihukum, dalam persidangan. Sedangkan yang meringankan terdakwa antara lain, terdakwa masih muda, dan terdakwa

\footnotetext{
${ }^{24}$ Moeljatno, 1993, Perbuatan pidana dan Pertanggung jawaban dalam Hukum Pidana, Bina Aksara, Jakarta
} 
menyesali perbuatannya. Apabila kaidah hukum itu dilanggar, maka kepada yang bersangkutan akan diberikan sanksi atau hukuman.

Peneliti merasa putusan yang diberikan sudah termasuk adil karena mengingat perbuatan terdakwa tersebut sudah merusak generasi bangsa bahwa hukuman yang berkeadilan adalah hukuman yang menjamin perlindungan masyarakat dari sebuah kejahatan yang dapat merusak dan menciderai suatu bangsa. Hal ini juga sudah sepantasnya bagi para pelaku tindak pidana narkotika dihukum seberat-beratnya karena perbuatannya sesuai dengan konsekuensi dan dampak yang akan ditimbulkan kelak secara sistematis dapat mengancam kerusakan moril bangsa dan juga untuk mendukung program pemerintah dalam pemberantasan narkotika.

Menurut peneliti jika dilihat dari kualifikasi tindak pidana yang dilakukan oleh terdakwa yakni melakukan dua delik sekaligus yakni melanggar Pasal 131 Undang-Undang Nomor 35 Tahun 2009 tentang Narkotika dan Pasal 5 ayat (1) huruf c Undang-Undang Nomor 8 Tahun 2010 tentang Pencegahan serta Pemberantasan Tindak Pidana Pencucian Uang mengingat terdakwa terdakwa Tarmizi bin Abdullah mengetahui kalau topik mempunyai pekerjaan menjual narkotika tetapi tidak dilaporkan oleh Terdakwa Tarmizi bin Abdullah pihak kepolisian RI ataupun kepada Badan Narkotika Nasional dan juga terdakwa memfasilitasi rumah terdakwa tersebut sebagai penampungan narkotika dan juga menikmati hasil dari uang yang diduga dari penjualan narkotika tersebut maka perbuatan terdakwa tersebut melakukan dua delik sekaligus atau bisa disebut dengan concurcus realis atau perbarengan tindak pidana. Peneliti menganalisis bahwa perbuatan terdakwa telah melanggar:

1) Pasal 131 Undang-Undang Nomor 35 Tahun 2009 tentang Narkotika ancaman hukuman 1 Tahun.

2) Pasal 5 ayat (1) huruf c Undang-Undang Nomor 8 Tahun 2010 tentang Pencegahan serta Pemberantasan Tindak Pidana Pencucian Uang ancaman Hukuman 5 Tahun

Menurut penelitian berdasarkan dari rumus penjatuhan sanksi pidana terhadap concursus realis tersebut jika diakumulasikan 1 Tahun $+(5$ Tahun: $1 / 3=2)=2$ Tahun +1 Tahun $=3$ Tahun 6 Bulan karena terdakwa tidak membayar denda, berarti hakim sudah tepat menerapkan ancaman hukuman bagi terdakwa yakni dengan hukuman 3 Tahun 6 Bulan.

Masalah putusan hakim ringan atau beratnya tergantung klasifikasi dari unsur tindak pidana yang dilakukannya. Demikian pula bagi terpidana dan pihak dari keluarga terpidana yang merasa putusan tersebut tidak adil, karena mereka menganggap hukuman terpidana terlalu berat. Semua boleh berpendapat dan mencari kesimpulan secara pribadi, apakah rasa adil/keadilan telah ada dalam putusan tersebut. Penulis hanya dapat menyatakan bahwa rasa adil/keadilan hanya ada pada Tuhan Yang Maha Esa, Sang Pencipta langit dan bumi serta segala isinya dan tidak ada satu orangpun yang dapat mewakili Tuhan, bahkan tidak bagi seorang hakim Terhebat sekalipun.

\section{Kesimpulan}

1. Pertanggungjawaban terhadap pelaku tindak pidana narkotika dan tindak pidana pencucian uang dalam putusan nomor: 124/Pid.Sus/2016/PN.JK. Berdasarkan hasil penelitian dilihat dikaji dari pertanggungjawaban pidananya terdakwa dari unsur kesalahan bahwa terdakwa dengan sengaja dolus menyewakan rumahnya untuk kepentingan topik dalam rangka menjual narkotika yang mana uang sewanya digunakan terdakwa untuk keperluan pribadi. Berdasarkan hal diatas tersebut terdakwa sudah dapat mengetahui dan membayangkan bahwa akibat perbuatan terdakwa tersebut yang bekerjasama dengan topik untuk menjual narkotika yang mana hasil keuntungan tersebut dipergunakan oleh terdakwa untuk keperluannya. 
2. Perbuatan terdakwa tersebut melanggar hukum dan dapat dikenai sanksi pidana, dari unsur kemampuan bertanggungjawab bahwa terdakwa terdakwa Tarmizi Bin Abdullah terdakwa tidak cacat jiwa atau terganggu jiwanya sehingga dapat dipertanggungjawabkan, dari sikap batin (mens rea) Terdakwa memiliki niat jahat dan secara willen en wetten karena terdakwa Tarmizi bin Abdullah mengetahui kalau topik mempunyai pekerjaan menjual narkotika tetapi tidak dilaporkan oleh Terdakwa Tarmizi bin Abdullah pihak kepolisian RI ataupun kepada Badan Narkotika Nasional dan tidak ada alasan pemaaf sehingga unsur pertanggungjawaban tersebut telah terpenuhi.

3. Putusan Pengadilan Nomor: 124/Pid.Sus/2016/PN.TJK apakah sudah memenuhi rasa keadilan yang berkemanfaatan. Dalam hal ini putusan yang diberikan sudah termasuk adil karena perbuatan terdakwa tersebut sudah merusak generasi bangsa dan mengingat perbuatan terdakwa tersebut melakukan dua delik sekaligus yakni melanggar Pasal 131 Undang-Undang Nomor 35 Tahun 2009 tentang Narkotika dan Pasal 5 ayat (1) huruf c Undang-Undang Nomor 8 Tahun 2010 tentang Pencegahan serta Pemberantasan Tindak Pidana Pencucian Uang,

\section{Daftar Pustaka}

A. Buku

Lastarya, Dharana, Narkoba, Perlukah Mengenalnya, Pakarkarya, Jakarta, 2006.

Moeljatno, 1993, Perbuatan pidana dan Pertanggung jawaban dalam Hukum Pidana, Bina Aksara, Jakarta.

Mappaseng, Erwin, Pemberantasan dan Pencegahan Narkoba yang dilakukan oleh polri dalam Aspek Hukum dan Pelaksanaannya, Buana Ilmu, Surakarta, 2002.

Nasution, Bismar, Hukum Kegiatan Ekonomi I, Books Terrace \& Library, Bandung,2007.

Sutedi, Adrian, Tindak Pidana Pencucian Uang, Citra Aditya Bakti, Bandung, 2008.

Sjahdeini, Sutan Remy. Pertanggungjawaban Pidana Korporasi, Rineka Cipta, Jakarta, 2007.

B. Jurnal

Adik Septiano Putra, Ni Putu Raiyuliartini, Dewa Gede Sudika Mangku. "Sistem Pembinaan Terhadap Narapidana Narkotika Di Lembaga Pemasyarakatan Kelas Ii B Singaraja. (n.d.). E-Journal Komunitas Yustisia Universitas Pendidikan Ganesha Program Studi Ilmu Hukum. $V$.

Catur Mei Wulandari, D. A. (2015). Faktor-Faktor Yang Mempengaruhi Penyalahgunaan Napza Pada Masyarakat Di Kabupaten Jember. Jurnal Farmasi Komunitas. Vol. 2. No. 1., 3.

D, R. K. (2014). Pertanggungjawaban Pidana Korporasi Berdasarkan Asas Strict Liability (Studi Pembaharuan Hukum Pidana Lingkungan Hidup). Jurnal Yuridis. Vol.1 No.2.

Darmawan, O. (2018). Pertanggungjawaban Pidana Korporasi Dalam Illegal Fishing Di Indonesia. Jurnal Yudisial. Vol. 11 No. 2, 183.

Eleanora, N. (2011). Bahaya Penyalahgunaan Narkoba Serta Usaha Pencegahan Dan Penanggulangannya (Suatu Tinjauan Teoritis). Jurnal Hukum: Fakultas Hukum Uinssula. Vol XXV.No. 1, 440.

Heryndra, M. F. (n.d.). Kajian Yuridis Kriteria Tentang "Personil Pengendali Korporasi” Terkait Pertanggungjawaban Pidana Korporasi Berdasarkan Pasal 6 ayat (1) Undang-undang Republik Indonesia Nomor 8 Tahun 2010 Tentang Pencegahan dan Pemberantasan Tindak Pidana.

Iriani, D. (2015). Kejahtan Narkoba: Penaggulangan, Pencegahan dan Penerpan Hukuman Mati. Jurnal Islamica. Vol. 12. No. 2, 307.

Migunani, M. F. (2014). Sosialisasi Dan Penyuluhan Narkoba. Jurnal Inovasi Dan Kewirausahaan. Vol. 3 No. 2, 73.

Mulyana, T. (2015). Kedudukan Jaksa Kpk Dalam Penuntututan Tindak Pidana Pencucian Uang 
Hasil Dari Tindak Pidana Korupsi. Jurnal Humaniora Scientica Vol. Ii No. 1.

Tommy J. Bassang. Pertanggungjawaban Pelaku Tindak Pidana Deelneming . (2015). Jurnal Lex Crimen. Vol. Iv. No. 5., 124.

Primanita Aisiy Nur Habibah, "Meningkatkan Pemahaman Siswa Tentang Bahaya Penyalahgunaan Narkoba Melalui Layanan Informasi. (n.d.). Indonesia Journal of Guidance and Counseling: Theory and Aplication.

Senjaya, O. (2018). Perbandingan Undang-Undang Nomor 35 Tahun 2009 Tentang Narkotika Dengan Ruu Kuhp Indonesia Berkaitan Dengan Sistem Pemidanaan Terhadap Pelaku Tindak Pidana Penyalahguna Narkotika . Jurnal Hukum Positum. Vol. 3, No. 1, 95.

Sholihah, Q. (2015). Efektivitas Program P4gn Terhadap Pencegahan Penyalahgunaan Napza. Jurnal Kesehatan Masyarkat. Vol.9. No. 10. No. 2., 155.

Toruan, H. D. (2014). Pertanggungjawaban Pidana Korupsi Korporasi . Jurnal Rechtsvinding. Vol. 3. No. 3.

Wulansari, M. A. (2918). Pengembangan Buku Panduan Pencegahan Bahaya Narkoba Bagi Siswa Sekolah Menengah Pertama. Jurnal Bk UNESA. Vol. 8. No. 1, 2.

C. Undang-undang

Undang-Undang Dasar 1945 Hasil Amandemen ke 4.

Undang-Undang Nomor 8 Tahun 1981 tentang Kitab Undang-Undang Hukum Acara Pidana.

Undang-Undang Nomor 2 Tahun 2002 tentang Kepolisian RI.

Undang-Undang Nomor 16 Tahun 2004 tentang Kejaksaan RI.

Undang-Undang Nomor 48 Tahun 2009 tentang Kekuasaan Kehakiman RI.

Undang-Undang Nomor 8 Tahun 2010 tentang pencegahan dan pemberantas tindak pidana pencucian uang.

Undang-Undang Nomor 35 Tahun 2009 tentang Narkotika.

Peraturan pemerintah nomor 95 tahun 2014 tentang perubahan kedua atas peraturan pemerintahan nomor 27 tahun 1983 tentang pedoman pelaksanaan kitab undang-undang hukum acara pidana. 
